\title{
LATE CABBAGE PLANTING DENSITY
}

\author{
Janko Červenski* ${ }^{*}$, Dario Danojević ${ }^{1}$, \\ Slađana Medić-Pap ${ }^{1}$, Aleksandra Savić ${ }^{1}$
}

\begin{abstract}
Late cabbage forms a large above-ground mass which requires certain vegetation space in order to thrive. Late cabbage planting density should therefore, start from at least $70 \mathrm{~cm}$ inter-row and $50 \mathrm{~cm}$ intra-row spacing. Transplanting at the required spacing gives 28.600 plants per hectare. The required spacing provides proper plant development, the formation of rosettes (over 70-80 cm) with large leaves, and compact cabbage heads. Applying cultivation techniques needed for cabbage production and proper spacing results in the formation of regular head mass and expected yield of late cabbage. Proper spacing also provides better use of agricultural mechanization without damage to cabbage heads. On the other hand, higher planting density increases production costs of transplantation, cultivation practices, and workforce.
\end{abstract}

Keywords: cabbage production, cabbage heads, transplanting,

\section{Introduction}

Cabbages are among the most widespread vegetables in the world. It grows on about 3 million ha, from which the head cabbage occupies and has the highest economic importance (Červenski et al., 2009). Production of cabbage in Serbia is carried out in the plains, river valleys, highlands and mostly around big cities, at about 11,000 hectares with an average yield of 26 tons per hectare (webrzs.stat.gov. rs, 2017). It is also possible at higher altitudes of up to two thousand meters. The dominant cabbage producers in Serbia are family households, while agriculture companies have a significantly smaller share in this vegetable crop production. Households took a larger market share due to high natural and fresh consumption, while significant amounts are also used for bio-fermentation (pickling). The size of cabbage production in Serbia is high, due to significantly higher consumption than the world average ( 20 pounds per capita), as determined by the good offer, consumer habits and relatively low market prices compared to other vegetable crops (Vlahović, 2015).
Late cabbage production in larger areas is often connected to the proximity of the market, so as to boost cost-effectiveness or efficiency of the production. Late cabbage production is widespread mostly due to consumer habit of cabbage pickling (Červenski and Takač 2012). This habit often determines the cabbage production area - market, such as Belgrade, Futog, Čačak, and so on. Producers are trying to increase and provide the maximum yield per unit area. In order to provide sufficient quantities of the product, deviations from the regular or proper crop management occurs, the fact unfortunately often misused by the producers. Late cabbage is grown in monoculture or even increasing plant density per unit area by 50 to $100 \%$. Producers often replant late cabbage at an intra-row spacing of $30 \mathrm{~cm}$ in an attempt to reach a higher number of plants per hectare, ie. higher yield per unit area.

Increase in planting density increases crop competition for nutrients, air, moisture, water and affects the size of the heads as well as cabbage yield (de Moel and Everaarts, 1990; Barrett et al., 2015). 




Figure 1. Cabbage heads damaged by mechanization (photo by Janko Červenski) Slika 1. Mehanička oštećenja glavica kupusa (fotografija Janko Červenski)

This intra-row spacing does not suit cabbage plants for several reasons. Higher plant density decreases plant spacing, resulting in fierce competition between individual plants for nutrients, water, light, and so on. It results in long robust plants, prone to lodging due to great weight and lack of vegetation space. Lodged plants continue their growth and development, taking up all the row spacing and thereby preventing inter-row cultivation and harvesting. Late cabbage heads are easily damaged or crushed by mechanization (Figure 1).

Červenski et al. (2010) emphasize the importance of proper and uniform intra-row and interrow spacing in cabbage production. The above-mentioned arguments and uniform direction of rows affect the quality of mechanized cabbage harvesting. Most of all, if cabbages are out of row direction or stems are set at an angle to the row direction, mechanized harvesting cabbage is aggravated and easily damages cabbage plants or heads (Figure 2).

Late cabbage is an intensive vegetable crop. The production is approached by a set of cultivation techniques without the so-called $» \bmod -$ ification in cultivation practices", with the increased use of high transplanting density. This paper aims to determine the suitable spacing, because of high plant density applied by the producers of late cabbage.

\section{Late cabbage transplantation}

Cabbage production requires high-quality transplants, which must be properly replanted (Červenski et al., 2009). Production of cabbage transplants at the same location for several years can cause the build-up of inoculum of pathogens, such as Pythium spp., Rhizoctonia
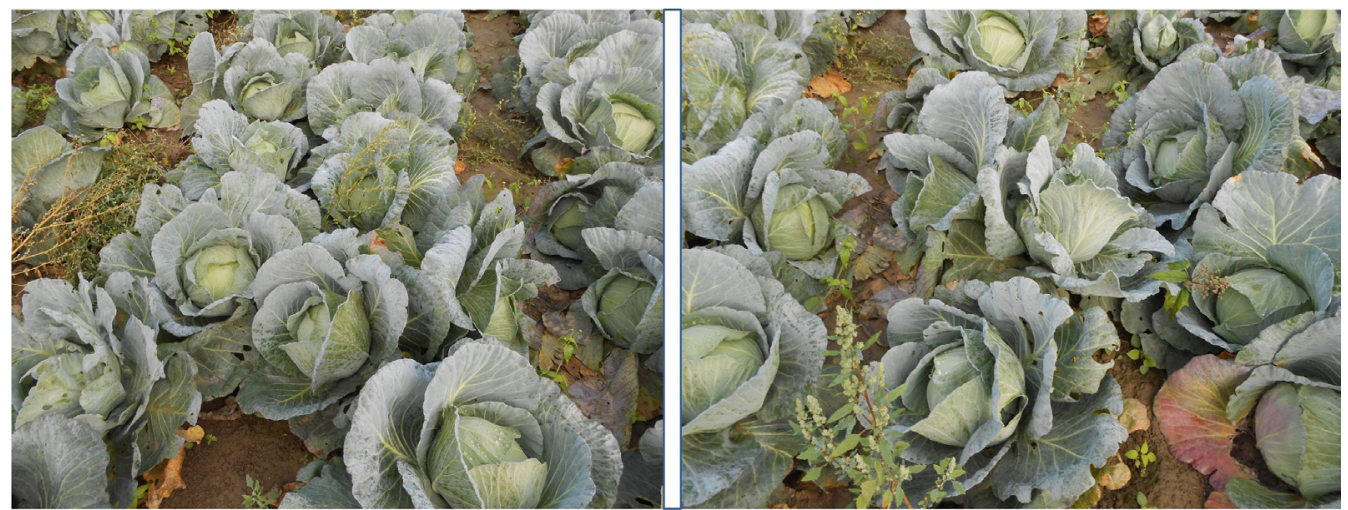

Figure 2. Irregular rows of late cabbage (photo by Janko Červenski) Slika 2. Nepravilni redovi kasnog kupusa (fotografija Janko Červenski) 
solani, Olpidium brassicae, Alternaria brassicae, Phoma lingam, Sclerotinia sclerotiorum, Botrytis cinerea. Another problem is that most of these species are polyphages. Due to the spread of diseases and harmful organisms in cabbage production or monoculture transplant production, a significant decrease in yield occurs while the soil is most often the source of inoculum. Cabbage plants should not be planted or re-planted in the same location consecutively for at least three years, even 4-5 years in case of disease occurrence (Medić-Pap et al., 2017).

Cabbage plants are transplanted at the stage of five or six well-developed leaves. Transplants should be screened before transplanting so that plants with damaged buds (future heads) as well as weak and diseased plants are discarded. The nursery should be well-watered the day before transplanting, because of quick root recovery.

The soil around the roots should be well compacted, to prevent air from entering as this may cause deterioration of plants. Width inter-row spacing depends on the width of cultivators. Late cabbage should be cultivated using the appropriate row spacing so that the plants could properly develop and form heads.
Transplants are watered immediately after transplanting and before planting, if necessary. Plants well-supplied with water quickly recover the root (Bošnjak et al., 2001).

The different quantity of cabbage plants is produced per hectare, from 20,000 to 70,000 plants/ha. Higher plant density increases yields and profits in cabbage production. However, the yield and quality of cabbage, as a result of plant density, reveal several factors affecting cabbage production such as choice of variety, climate, soil, water availability, the status of nutrients, market demands and so on (Žnidarčić et al., 2007).

Plant density is an important part of the production for maximum yield and equal maturity of plants. Differentiation of plant density per unit area provides the ability to regulate the size of the edible plant parts. The optimal plant density can be achieved only by using an appropriate inter-row and intra-row spacing (Turbin et al., 2014), (Figure 3).

Semuli (2005) indicated that reduced cabbage plant spacing causes increased competition for nutrients, light, air and moisture, which in turn may result in a reduced head diameter and



Figure 3. Uneven density of late cabbage (photo by Janko Červenski)

Slika 3. Neujednačena gustina kasnog kupusa (fotografija Janko Červenski) 
weight. High plant density should be avoided in late cabbage production, as each plant needs optimal spacing for growth and development (Figure 4). Inter-row spacing often depends on the width of cultivator and mechanization. Transplanting late cabbage at $70 \times 50 \mathrm{~cm}$ spacing results in 28,600 plants per hectare. Late cabbage can properly grow and develop at this planting density (Červenski, 2010). A total of 25,000 to 40,000 plants per hectare should be obtainable in late cabbage production. Above mentioned spacing was proposed by Moravčević et al. (2005), while Maksimović et al. (2008) reported the use of planting distance of $70 \times 70 \mathrm{~cm}$ in late cabbage production, with 20,408 plants obtained per hectare.

According to Kolota et al. (2015) inter-row spacing of $45 \mathrm{~cm}$, and intra-row spacing of 40 $\mathrm{cm}$ provides 55,000 plants per hectare is optimal for the production of cabbage plants with heads about $1.0-2.0 \mathrm{~kg}$, as are requirements of fresh consumption. Consumer trends on green markets of Europe and America prefer cabbage heads with a mass of $1-2 \mathrm{~kg}$. Higher planting density reduces the size of heads. Increasing the cabbage plant density per hectare of 44,000 to 74,000 results in decreasing yields with heads weighing above $2 \mathrm{~kg}$, while the density of 63,000 and 74,000 per hectare increases costs of production with a proportional increase in dose fertilization.

Cabbage intended for late autumn or winter production, transplanted at $70 \mathrm{~cm}$ inter-row and $40-60 \mathrm{~cm}$ intra-row spacing, results in 25,000 to 35,000 plants per hectare (Matotan, 2008). Stepanovic et al. (2000) studied crop density of cabbage (20,400 to 47,620 plants/ha) over a two-year trial examining the following properties on cabbage: plant height, number of leaves in the rosette, head diameter and head weight. The authors agreed that planting density greatly affects the formation of cabbage plants. They also report the highest yield of cabbage ( $49.38 \mathrm{t} / \mathrm{ha}$ ) realized in the density of 33,715 cabbage plants per hectare.

Studies of Karagić (1998) were related to the production of late double-cropped cabbage cultivar Futoški, planted at inter-row spacing of $60 \mathrm{~cm}$ and $50 \mathrm{~cm}$ spacing of plants in a row.

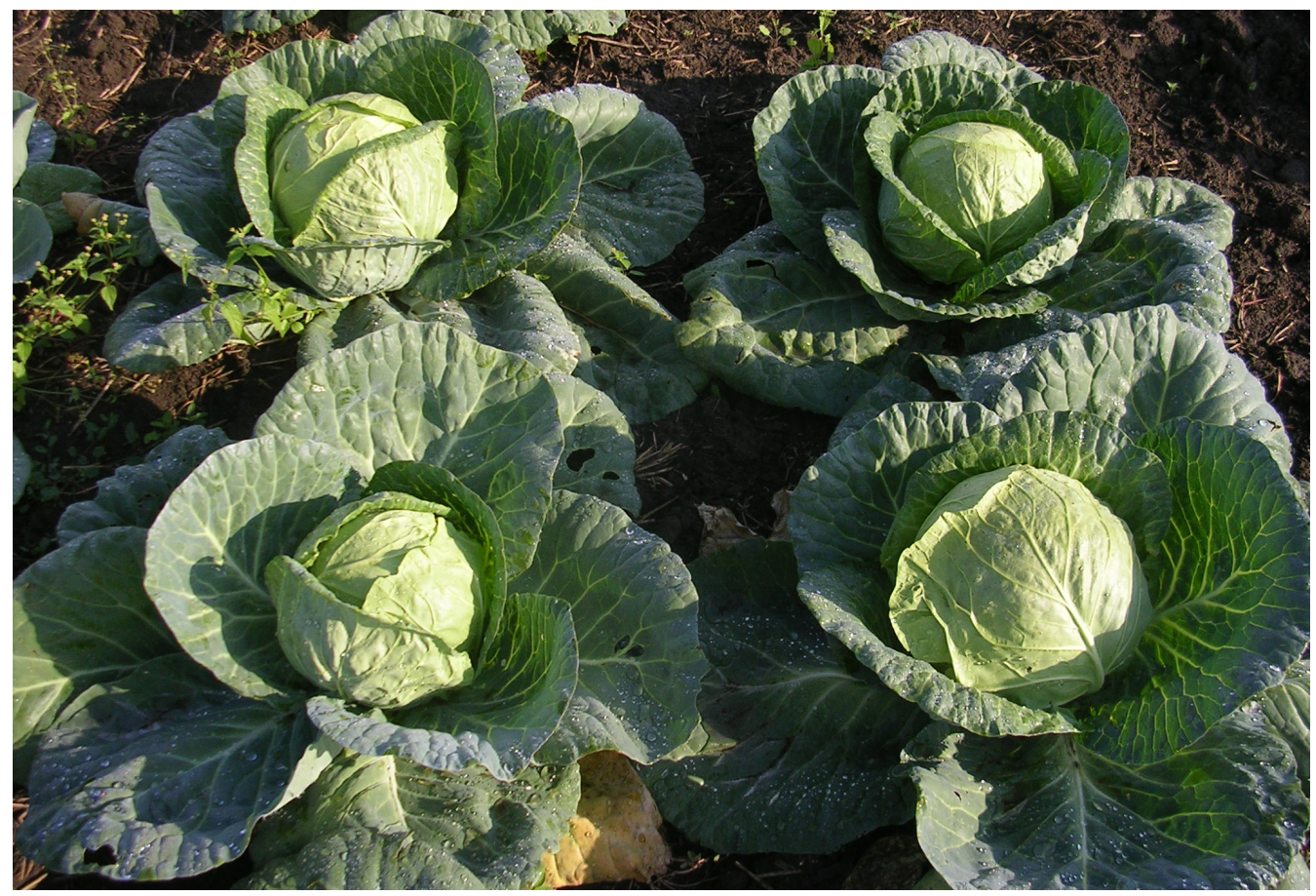

Figure 4. Optimal cabbage planting density (photo by Janko Červenski) Slika 4. Optimalna gustina rasađivanja kupusa (fotografija Janko Červenski) 
This author obtained the yield of 49.3 to $57 \mathrm{t} / \mathrm{ha}$ using the above-mentioned spacing. The same author emphasizes the importance of pre-irrigation soil moisture, effects of water consumption on evapotranspiration, as well as effects of climatic conditions on production.

Results of Haque et al. (2015) indicate that cabbage yield per hectare is under the joint effect of applied nitrogen and proper spacing. Higher doses of nitrogen increased the number of leafless plants, thereby increasing gross yield, but ultimately reducing market yields. The yield increased due to optimal levels of nitrogen and planting density. Production costs increased due to increased amounts of nitrogen. The maximum ratio of the cost and yield was obtained during the application of $250 \mathrm{~kg} \mathrm{~N} / \mathrm{ha}$ at $50 \times 50$ $\mathrm{cm}$ spacing. Authors recommend this combination of nitrogen fertilization and spacing for a successful cabbage production.

\section{Conclusion}

Late cabbage forms a large above-ground mass, which requires certain vegetation space in order to thrive. Planting density of late cabbage should be at minimum $70 \mathrm{~cm}$ inter-row spacing, and $50 \mathrm{~cm}$ intra-row spacing, which results in 28,600 plants per hectare. This planting density allows proper development of plants, the formation of leaf rosettes (over 70-80 cm) with large leaves and the formation of compact heads with proper head weight and the expected yield, provided that all mandatory cultivation practices in cabbage production are applied. Proper spacing also allows better use of machinery, without the possibility of damaging cabbage heads. On the other hand, higher planting density increases the costs of cabbage transplant production, as well as the costs of crop management and workforce.

\section{Acknowledgements}

Authors gratefully acknowledge the support from the Ministry of Education, Science and Technological Development of the Republic of Serbia (Project TR 31030).

\section{References}

Barrett CE, Zotarelli L, Paranhos LG, Dittmar D, Fraisse CW, VanSickle JJ (2015): Optimum planting configuration for high population plasticulture grown cabbage. HortScience, 50:1472-1478.

Bošnjak Đ, Karagić Đ (2001): Potrebe za vodom i zalivni režim kasnog kupusa u Vojvodini. Savremena poljoprivreda, Novi Sad, Vol. 50 (1-2): 123-126.

Červenski J, Gvozdenović Đ, Gvozdanović-Varga J, Kondić S (2009): Tehnologija proizvodnje rasada za kasnu proizvodnju kupusa, Zbornik radova Instituta za ratarstvo i povrtarstvo Novi Sad, 46: 229-234.

Červenski J (2010): Gajenje kupusa - monografija, SZR Tampograf, Novi Sad, 199.

Červenski J, Gvozdenović Đ, Takač A, Glogovac S (2009): Description of a new summer cabbage cultivar. Selekcija i semenarstvo, 15(3): 37-41.

Červenski J, Gvozdenović Đ, Vlahović B, Bošnjak Dj, Vračar Lj (2010): Berba i čuvanje kupusa. Ratarstvo i povrtarstvo, Vol. 47 (1): 357-362.

Červenski J, Takač A (2012): Growing cabbage as a double crop. Ratarstvo i povrtarstvo, Vol. 49 (1): 75-79.

De Moel CP, Everaarts AP (1990): Growth development and yield of white cabbage in relation to time of planting. Acta Hortic., 267: 279-288.

Haque FA, Islam N, Islam MN, Ullah A, Sarkar MD (2015): Growth, Yield and Profitability of Cabbage (Brassica oleracea L.) as Influenced by Applied Nitrogen and Plant Spacing. The Agriculturists 13(1): 35-45.

Karagić Đ (1998): Evapotranspiracija, prinos i kvalitet kupusa u zavisnosti od predzalivne vlažnosti zemljišta i roka sadnje. Magistarska teza, Poljoprivredni fakultet, Novi Sad.

Kołota E, Chohura P (2015): Control of head size and nutritional value of cabbage by plant population and nitrogen fertilization. Acta Sci. Pol. Hortorum Cultus, 14(2): 75-85.

Maksimović L, Milić S, Červenski J, Pejić B (2008): Proizvodnja kupusa u postrnoj setvi. Zbornik radova Instituta za ratarstvo i povrtarstvo Novi Sad, Vol.45, (2): 187-195. 
Matotan Z (2008): Zeljasto povrće, Neron, Bjelovar, 156.

Medić-Pap S, Červenski J, Danojević D (2017): Plodored u proizvodnji kupusa kao prevencija pojave štetnih organizama. Biljni lekar, 45, (3): 293-302.

Moravčević Đ, Bjelić V, Vučković S (2005): Effects of crop density on fodder yield in cabbage production. Biotechnology in Animal Husbandry, Vol. 21 (5-6-2): 159-162.

Semuli KLH (2005): Nitrogen requirements for cabbage (Brassica oleracea capitata) transplants and crop response to spacing and nitrogen top-dressing. M. Sc. Thesis, University of Pretoria, 57.

Stepanovic MV, Bjelic VV, Dragicevic VD (2000): Effect of crop density on morpho- logical characteristics and yield of cabbage. Acta Horticult., 533: 205-207.

Turbin VA, Sokolov AS, Kosterna E, Rosa $\mathrm{R}$ (2014): Effect of plant density on the growth, development and yield of brussels sprouts (Brassica oleracea L. var. gemmifera L.). Acta Agrobotanica, Vol. 67 (4): 51-58.

Vlahović B (2015): Tržište agroindustrijskih proizvoda. Univerzitet u Novom Sadu, Poljoprivredni fakultet, Novi Sad, 339.

Žnidarčić D, Kacjan-Maršić N, Osvald J, Požrl T, Trdan S (2007): Yield and quality of early cabbage (Brassica oleracea L. var. capitata) in response to within-row plant spacing. Acta agriculturae Slovenica, 89 (1): 15-23.

http://webrzs.stat.gov.rs

\title{
GUSTINA SADNJE KASNOG KUPUSA
}

\author{
Janko Červenski, Dario Danojević, Slađana Medić-Pap, Aleksandra Savić
}

\section{Sažetak}

Kasni kupus formira veliku nadzemnu masu, koja za svoj razvoj zahteva određeni vegetacioni prostor. Zbog toga bi trebalo da je sklop kasnog kupusa od minimalnih $70 \mathrm{~cm}$ međurednog razmaka i $50 \mathrm{~cm}$ razmaka između biljaka u redu. Rasađivanjem na pomenuti razmak dobijamo 28.600 biljaka po hektaru. Ovakav sklop omogućuje pravilan razvoj biljaka, dalje formiranje lisne rozete (preko $70-80 \mathrm{~cm}$ ) sa krupnim listovima i na kraju obrazovanje pravilne i dobro zbijene glavice kupusa. Sa ovakvim sklopom kasnom kupusu je omogućeno da formira pravilnu masu glavice i da se dobije očekivani prinos, naravno uz poštovanje svih principa agrotehnike neophodnih za proizvodnju kupusa. Takođe pravilan skop omogućuje kvalitetniji prohod mehanizacije bez mogućnosti oštećivanja glavica gaženjem. Gušći sklop na drugoj strani povećava troškove proizvodnje rasada kupusa, troškove agrotehnike, ali i radne snage za sečenje glavica.

Ključne reči: proizvodnja kupusa, glavica kupusa, rasađivanje.

Primljen: 30. 10. 2018.

Prihvaćen: 1. 11. 2018. 